\title{
Aşırı Düşük Doğum Ağırlıklı Prematüre Çocukların Okul Öncesi Dönemde Dünya Sağlık Örgütü Çocuk ve Ergenlerde Uluslararası İşlevsellik Sınıflamasında Belirlenen Alanlarda Sorun Yaşama Oranları ve Hizmet Gereksinimleri
}

\author{
Problem Rates and Service Requirements of Extremely Low Birth Weight \\ Preschoolers in Areas Designated in the World Health Organization \\ International Classification of Functioning in Children and Adolescents \\ (ICF-CY) System
}

\author{
Berfin Uysal' ${ }^{10}$, Sultan Kavuncuoğlu² (D) \\ 'Sağlık Bilimleri Üniversitesi, Bursa Șehir Hastanesi, Çocuk Nefroloji Bölümü, Bursa, Türkiye \\ 2Sağlık Bilimleri Üniversitesi, Kanuni Sultan Süleyman Eğitim ve Araştırma Hastanesi, Yenidoğan Bölümü, İstanbul, Türkiye
}

\section{ORCID ID: B.U. 0000-0001-6267-0454; S.K. 0000-0002-6323-8994}

Cite this article as: Uysal B, Kavuncuoğlu S. Aşırı düşük doğum ağırlıklı prematüre çocukların okul öncesi dönemde dünya sağlık örgütü çocuk ve ergenlerde uluslararası işlevsellik sınıflamasında belirlenen alanlarda sorun yaşama oranları ve hizmet gereksinimleri. Experimed 2021; 11(2): 102-12.

öz

Amaç: Bu çalışmada, 1000 gram ve altında doğan ve 3-5 yaşına gelmiş çocukların, Dünya Sağlık Örgütü Çocuk ve Ergenlerde Uluslararası İşlevsellik Sınıflaması (ICF-CY) sisteminde belirlenen alanlarda sorunla karşılaşma oranları araştırılarak ve hizmet ihtiyaçlarının belirlenmesi amaçlanmıştır.

Gereç ve Yöntem: Elli sekiz çocuğa okul öncesi dönemde fizik muayene ve ayrıntılı nörolojik inceleme yapıldı. Bu çocuklar perinatal ve sosyodemografik özellikler yönünden irdelenerek tüm çocuklara Vineland Uyum ve Davranış Ölçeği uygulanmıştır. Sonuçlar ICFCY modeline uyarlanmıştır.

Bulgular: Olgularımızın iletişim işlevselliğinde \%20,6'sının, günlük yaşam becerilerine katılımında \%12,1'inin, sosyalleşme işlevselliğinde \%19'unun, hareket işlevselliğinde ise $\% 29,3$ 'ünün ciddi düzeyde sorun yaşadıkları saptanmıştır. Sadece 3 olguda ciddi düzeyde yaşla uyumlu olmayan davranış sorunu tanımlanmıştır. Hareket işlevselliğinin; öz bakım işlevselliğini, ev yaşamı etkinliklerine katılımı, sosyalleşme işlevselliğini, oyun ve boş zaman etkinliklerine katılımı, öğrenme ve problem çözme işlevselliğini anlamlı olarak etkilediği belirlenmiştir. Olgularımızın \%22,4'ünün (13 olgu) yüksek seviyede özel eğitim desteğine ihtiyacı olduğu belirlenmiştir.

Tartışma: Günümüzde yaşama şansları oldukça yüksek olan aşırı düşük doğum ağırlıklı prematürelerin işlevsellik, etkinlik, yaşama

\begin{abstract}
Objective: Our aim was to determine the problem rates and service requirements according to the World Health Organization International Classification of Functioning in Children and Adolescents (ICF-CY) system defining specified areas such as body structures, functionality, activity, participation in life and environmental factors in premature children born weighing $<1000 \mathrm{~g}$ and aged 3 to 5 years during the research process.
\end{abstract}

Material and Method: The physical and neurological examination results and perinatal and sociodemographic characteristics were examined for 58 preschoolers who had been born prematurely and they were evaluated in terms of communication, socialization, movement, and daily living skills using the Vineland Adaptation and Behavior Scale. The results were adapted to the ICF-CY model.

Results: The proportions of functionality problems of our cases were found to be $20.6 \%$ for communication, $12.1 \%$ for participation in daily life skills, $19 \%$ for socialization and $29.3 \%$ for movement. Severe behavioral problems incompatible with age were identified in only 3 cases. Movement functionality was determined to significantly affect self-care functionality, participation in home life activities, socialization functionality, participation in games and leisure activities, and learning and problem solving function- 
katılım ve hizmet ihtiyaçlarının saptanabilmesi için uzun dönem izlemleri çok önemlidir ve mutlaka ergenlik dönemine kadar devam ettirilmelidir.

Anahtar Kelimeler: Prematüre, aşırı düşük doğum ağırlıklı, Dünya Sağlık Örgütü, Vineland, özel eğitim

\section{GíRiş}

Günümüzde çok düşük doğum ağırlıklı (ÇDDA) bebeklerin yaşatılma başarısı yalnızca yaşama oranları ile değil erken ve uzun dönemde yaşam kalitelerini yansıtan nörolojik ve gelişimsel durumları kapsamında değerlendirilmektedir. ÇDDA ve aşırı düşük doğum ağırlıklı (ADDA) çocukların büyük bir çoğunluğunun çocukluk döneminde duygusal, davranışsal ve uyum sorunlarının olduğu gösterilmiştir (1). Doğum ağırlığının düşük olması ve gebelik haftasının az olması çocuğun ileri döneminde bu sorunlarının olabileceğinin en iyi göstergesidir. Bu sorunlar çocuğun yaşamakta olduğu sağlık sorunları, ev ortamı, sosyokültürel ve ekonomik düzey, anne-baba eğitimi, gelişimsel durum, sosyal stresler ve özellikle aile ve toplum desteklerinin birbirleriyle olan ilişkilerine bağlıdır. Aynı zamanda bu bileşenlerin her biri diğerini etkileyebilen faktörlerdir ve bunların tamamı bir bütün olarak çocuğun sağlık durumunu belirler. Çocuğun gelişimi ve davranışsal sorunları ve iyi olma hali arasındaki karmaşık ilişkiyi anlayabilmek için bugüne kadar çeşitli modeller öne sürülmüştür. Bu anlamda İşlevsellik, Yetiyitimi ve Sağlığın Uluslararası Sınıflaması (International Classification of Functioning, Disability and Health-ICF) modeli; vücut fonksiyonları, vücut yapısı, etkinlikler ve katılım bileşenleri ile bireyin sağlık ve yetiyitimi durumunu belirlemektedir (2).

Batı ülkelerinde ve ABD'de çocuklarda uyum performansını ölçebilen çok sayıda yöntem kullanılmaktadır. Bunlar içinde en gözde olanlardan biri Vineland Uyum Davranış Ölçeğidir $(3,4)$. Bu test, 0 -18 yaş arası çocukların iletişim, sosyalleşme ve hareket işlevselliğini, günlük yaşam becerilerine katılımını ölçen altın standart bir testtir. Gelişmiş ülkelerde, çok düşük doğum ağırlığı ile doğan bebeklerin okul öncesi dönemde gözlenen gelişimsel sorunları ile ilgili çok sayıda çalışma olmasına karşın ülkemizde ve benzer sosyoekonomik özellikler taşıyan gelişmekte olan ülkelerde bu alanda yapılmış çalışma sayısı azdır (5). Bu çalışmada ünitemizde, 1000 gram ve altında doğan ve 3-5 yaşına gelmiş prematüre bebeklerin, Dünya Sağlık Örgütü Çocuk ve Ergenlerde Uluslararası İşlevsellik Sınıflaması (ICF-CY) sisteminde tanımlanan alanlarda sorun yaşama oranlarının ve hizmet gereksinimlerinin belirlenmesi planlanmıştır.

\section{GEREÇ VE YÖNTEM}

Çalışmaya Sağlık Bakanlığı İstanbul Bakırköy Kadın Doğum ve Çocuk Hastalıkları Eğitim ve Araştırma Hastanesinde 1 Ocak 2005 ile 31 Aralık 2007 tarihleri arasında 1000 gram ve altında doğup İstanbul sınırları içerisinde yaşayan ve ebeveynlerinden ality. It was determined that $22.4 \%$ of our cases (13 cases) needed a high level of special education support.

Conclusion: Long-term follow-up is very important in determining the functionality, efficiency, participation in life, and service needs of extremely low birth weight premature babies whose survival rates are gradually increasing and should be continued with a multidisciplinary approach until adolescence.

Keywords: Premature, extremely low birth weight, World Health Organization, Vineland, special education

çalışmaya katılmak için yazılı onay alınmış olgular dahil edildi. Başka bir merkezde doğup hastanemize kabul edilen, hastanemizde doğup yer olmaması nedeniyle sevk edilen ve İstanbul sınırları dışında yaşayan olgular çalışma dışı bırakıldı.

Çalışmaya alınan prematürelere ait erken dönem neonatal dönem kayıtları veri tabanı ve hasta dosyalarından elde edildi. Perinatal dönem özelliklerinden erken membran rüptürü ve klinik koriyoamniyonit irdelendi. Erken neonatal özelliklerden gebelik haftası, doğum ağırlığı, yoğun bakım gereksinimi, ventilatörde kalış süresi, sürfaktan kullanımı, nekrotizan enterokolit (NEK), germinal matriks intraventriküler kanama (GM-iVK), respiratuar distress sendrom (RDS), serebral palsi, sepsis, konvülziyon, hiperbilirubinemi, patent duktus arteriozus (PDA), prematüre retinopati (ROP), postnatal steroid tedavisi ile toplam hastanede yatış süresi sorgulandı ve araştırma formuna kaydedildi. Prematüre takip polikliniği kayıtlarından postneonatal döneme ait bilgilere ulaşıldı, özellikler kaydedildi. Ailelere telefon ve mektupla ulaşılarak çalışma anlatıldı. Çalışmaya katılmak isteyenlere randevu verilerek çocuk ve ebeveyn çağrıldı. Randevu günü aile çalışmayı yapan hekim tarafından karşılandı, yapılacak muayene ve test anlatıldı. Onam alındı. ìlk değerlendirme sonuçları forma kaydedildi.

Olguların değerlendirildiği ortam düzenlendi. Olabildiğince izole, sessiz, test ve değerlendirmeler yapılırken çocuğun ve ailenin dikkatini dağıtmayacak rahat bir ortam sağlandı. Prematürelere genel fizik muayene yapıldı; ağırlık, boy ölçümü yanında Amiel-Tison metodu ile nörolojik muayenede sekel, yetersizlik araştırıldı. Nörolojik muayenede patoloji saptanan olgulara pediatrik nöroloji konsültasyonu yapıldı ve izleme alındı. Rehabilitasyon gerekenler özel eğitime yönlendirildi.

Ailelerin sosyodemografik durumunu belirleyebilmek için akraba evliliği, anne-baba eğitim düzeyi, anne-baba mesleği, kardeş sayısı, kardeş öğrenim durumu, konut durumu, aynı evde yaşayan birey sayısı, konutun ısınması, özel arabaya sahip olma, sağlık güvencesi gibi özelliklerden oluşan 19 soruluk bir form oluşturuldu ve her bir olgu için bu sorular ailelere soruldu.

Çalışmaya alınan prematüre çocuklara Vineland Uyum Davranış Ölçeği-2 uygulandı. Çalışma öncesinde Vineland Uyum Davranış Ölçeği-2'yi uygulayan hekim Ankara Üniversitesi Tıp Fakültesi Gelişimsel Pediatri Bilim Dalı́nda 2 hafta süre ile eğitim aldı.

Testin uyum becerilerini kapsayan dört ana alanı ve onbir alt alanı olup bu alanlar; iletişim (alıcı, anlatım, yazılı), günlük yaşam becerileri (kişisel, evdeki beceriler, toplumsal), sosyalleşme 
(kişiler arası ilişkiler, oyun ve boş zaman, başa çıkma becerileri) ve hareket (ince, kaba) tüm olgularda ayrı ayrı değerlendirildi. Aynı zamanda her olgu için 36 adet uyumlu olmayan davranış maddeleri soruldu. Çocuklara her zaman yapabildikleri maddeler için ' 2 ' puan, hiçbir zaman yapamadıkları maddeler için ' 0 ' puan, bazen yapıp bazen yapamadıkları maddeler için ' 1 ' puan verildi. Bazı özel maddelerde 'fırsat yok' seçeneği kullanıldı. Puanlar verildikten sonra her hasta için alt alanlar ve uyumlu olmayan davranışlar için v-skala skor, alanlar ve uyumlu davranış bileşkesi için standart skor hesaplandı. Tüm olgularımız ICFCY'de belirlenen alanlarda sınıflandırıldı. Buna göre Vineland Uyum ve Davranış Ölçeğinde aldıkları puan $<-2$ SD ise ciddi, $<$ -1 SD ise hafif-orta düzeyde sorun var olarak kabul edildi. Testin uygulanma süresi ortalama 45-60 dk arasında idi.

Çalışmada elde edilen bulgular değerlendirilirken istatistiksel analizler için SPSS 14,0 paket programı kullanıldı. Çalışma verileri değerlendirilirken tanımlayıcı istatistiksel metodların (ortalama, standart sapma, frekans) yanısıra niceliksel verilerin karşılaştırılmasında Student-t testi kullanıldı. Sürekli değişkenlerin karşılaştııılmasında Spearman korelasyon analizi ve Mann-Whitney $\mathrm{U}$ testi kullanıldı. Niteliksel verilerin karşılaştırılmasında ise Ki-Kare testi, Fisher's Exact test ve tanı tarama testleri kullanıldı. Sonuçlar \%95'lik güven aralığında anlamlılık $p<0,05$ düzeyinde değerlendirildi.

\section{BULGULAR}

Sağlık Bakanlığı Bakırköy Kadın Doğum ve Çocuk Hastalıkları Eğitim ve Araştırma Hastanesi 3. düzey yoğun bakım ve 2. düzey prematüre servislerinde, 1000 gram altında doğan toplam 162 prematüre bebek izlendi. Toplam 14 bebek kaybedildi, 21 bebek ise hastanemizde 3 . düzey yenidoğan yoğun bakım ünitesinde yer olmaması nedeni ile sevk edildi. Serviste izlenen hastalarımızın 18'i başka hastanelerden tarafımıza sevk edilen hastalardı. Kalan 109 hastadan 26'sı İstanbul dışında oturdukları için çalışmaya dahil edilmedi. Geriye kalan 83 vakadan 19'una adres ve telefon değişikliği nedeni ile ulaşılamadı. Ulaşılan 64 hastanın velisine araştırma hakkında bilgi verildi ancak 6 hastanın ailesi çocukları ile igili bir sıkıntıları olmadığı ve çalışmaya katılmaya gerek duymadıklarını belirterek katılmayı reddettiler. Sonuçta 58 hasta çalışmaya dahil edildi. Olgularımızın 37'si kız $(\% 63,8), 21$ 'i erkek $(\% 36,2)$ idi. Ortalama doğum ağırlığı $877,6 \pm 102,1$ gram, ortalama gebelik haftası $28 \pm 2,36$ hafta idi. Olgularımız ortalama $22,1 \pm 23,18$ gün yoğun bakım ünitesinde, 59 $\pm 21,2$ gün hastanede yatırıımıştı. Hastalarımızda görülen prematüre sorunları Tablo 1'de gösterilmiş̧ir.

Hastalarımızın ICF-CY Sınıflamasına Göre Gelişimsel İşlevler ve Etkinlikler ve Katılım Alanlarında Sorun Yaşama Oranları

\section{ILETişim}

\section{Alıcı dil}

Koryoamnionit olmayan hastaların \%5,7'sinde alıc dil işlevselliğinde ciddi düzeyde sorun mevcut iken annesinde koryoamnionit olanların \%40'ında ciddi düzeyde sorun saptandı ve ara-

\begin{tabular}{llll}
\hline $\begin{array}{l}\text { Tablo 1. Olgularımızda görülen prematüre sorunlarının } \\
\text { oranları. }\end{array}$ & $\mathbf{n}$ (olgu sayısı) & $\%$ \\
\hline & & 20 & 34,5 \\
\hline RDS & 29 & 50 \\
\hline Sepsis & & 6 & 10,3 \\
\hline Menenjit & Evre-1 & 12 & 20 \\
\hline \multirow{2}{*}{ NEK } & Evre-2 & 4 & 6,8 \\
\cline { 2 - 4 } & Evre-3 & 1 & 1,7 \\
\hline & Evre-1 & 12 & 20,7 \\
\cline { 2 - 4 } & Evre-2 & 8 & 13,8 \\
\cline { 2 - 4 } & Evre-3 & 2 & 3,4 \\
\cline { 2 - 4 } GM-iVK & Evre-4 & 1 & 1,7 \\
\hline PVL & & 5 & 8,6 \\
\hline Hidrosefali & & 2 & 3,4 \\
\hline haPDA & & 9 & 15,5 \\
\hline ROP & & 32 & 55,1 \\
\hline BPD & & 24 & 41,4 \\
\hline
\end{tabular}

RDS: Respiratuar distress sendromu, NEK: Nekrotizan enterokolit, GM-IVK: Intraventriküler kanama, PVL: Periventriküler lökomalazi, haPDA: Hemodinamik anlamlı patent duktus arteriozus, ROP: Prematüre retinopatisi BPD: Bronkopulmoner displazi

larındaki ilişki anlamlı bulundu. Aynı şekilde annenin öğrenim durumu, annenin çalışma durumu, babanın işinin olup olmaması, kendine ait bir odanın olup olmaması ile alıcı dil işlevselliği arasında anlamlı bir ilişki saptandı (Tablo 2). Çekirdek aile olmayan 4 hastadan hepsinin alıcı dil işlevlerinin normal olduğu görülürken çekirdek ailesi olanların \%24,1'inde alıcı dil işlevlerinde sorun olduğu tespit edildi. İşitme kaybı olanların alıc dil işlevlerinde anlamlı olarak daha ciddi sorun olduğu saptandı. Annesinde erken membran rüptürü (EMR) olan ve GM-IVK, periventriküler lökomalazi (PVL) geçiren olgularımız alıcı dil işlevselliğinde daha fazla oranda sorun yaşamalarına rağmen aralarındaki ilişki anlamlı değildi. Alıcı dil işlevselliğinde sorun yaşayan olgularımızın \%15,5'i (9 olgu) özel eğitim almıyordu. Bu olgularımızın anne ve baba eğitim düzeyinin daha düşük olduğu saptandı.

\section{Anlatım dili}

Sepsis ve menenjit geçiren olgular anlatım dili işlevselliğinde daha ciddi sorunlar yaşamasına rağmen aradaki ilişki anlamlı bulunmadı.

Annesi çalışan bebeklerin anlatım dili işlevselliği annesi ev hanımı olan bebeklere göre anlamlı olarak daha iyi bulundu. Aynı 
Tablo 2. Alııı dil işlevselliği ile annenin öğrenim ve çalışma durumu arasındaki ilişki.

\begin{tabular}{llccc}
\hline & & \multicolumn{3}{c}{ Alıcı dil işlevselliği (n) } \\
\cline { 2 - 5 } & & Ciddi düzey & Hafif-orta düzey & Sorun yok \\
\hline \multirow{3}{*}{$\begin{array}{l}\text { Annenin } \\
\text { öğrenim durumu* }\end{array}$} & Okuryazar değil & 0 & 1 & 1 \\
\cline { 2 - 5 } & Illk-Orta-Lise mezunu & 5 & 7 & 39 \\
\cline { 2 - 5 } & Yüksek okul mezunu & 0 & 0 & 5 \\
\hline $\begin{array}{l}\text { Annenin } \\
\text { çalışma durumu* }\end{array}$ & Ev hanımı & 5 & 7 & 11 \\
\hline Çalışıyor & 0 & 1 & \\
\hline *: p<0,05, n: Olgu sayısı & & & & 14 \\
\hline
\end{tabular}

şekilde kendisine ait bir odası ve oyun odası olanların olmayanlara göre bu alandaki durumları daha iyi idi (sırayla $p=0,025$, $\mathrm{p}=0,001)$. Anlatım dili işlevselliğinde sorun olan 42 hastanın 37 'si (\%88) özel eğitim almıyordu. Ciddi düzeyde sorun yaşayan 12 hastanın ise 9'u özel eğitimden faydalanmıyordu.

\section{Yazılı dil}

Olgularımız incelendiğinde yazııı dil işlevselliği ile herhangi bir prematüre sorunu arasında anlamlı bir ilişki saptanmadı. Hastalarımızın sosyodemografik özellikleri ile yazılı dil işlevselliği arasında da anlamlı bir ilișki bulunmadı.

\section{GÜNLÜK YAŞAM BECERILERI}

\section{Öz bakım}

Çalışan annelerin çocuklarının öz bakımlarının anlamlı olarak daha iyi olduğu görülürken aynı şekilde annenin eğitim durumu ile öz bakım işlevselliği arasında anlamlı bir ilişki saptandı (Tablo 3). Olgularımızın arasında annesinde EMR olanların ve
PVL, NEK sorunlarını yaşayanların öz bakım işlevselliklerinde daha ciddi sorunlar yaşadığı görüldü. Aynı şekilde hareket işlevselliği ile öz bakım işlevselliği arasında çok anlamlı bir ilişki saptandı (Tablo 3). Anne dışında bakıcısı olan olgularımızın öz bakım işlevselliğinin daha iyi olduğu görüldü $(p=0,04)$. Çalışmamızda kendine ait odası olanların da öz bakım işlevselliğinin anlamlı olarak daha iyi düzeyde olduğu saptandı. Öz bakım işlevselliğinde ciddi düzeyde sorun yaşayan 12 hastanın 8'inin fizik tedavi almadığı görüldü.

\section{SOSYALLEŞME}

\section{Kişiler arası ilişkiler}

Annesinde koryoamnionit olan, sepsis geçiren, bronkopulmoner displazi (BPD) sorunu olan ve steroid tedavisi alan olgularımızın kişiler arası ilişkilerde anlamlı olarak daha ciddi sorun yaşadıkları saptanırken GM-IVK, posthemorajik hidrosefali, menenjit, PVL varlığında bu fark istatistiksel olarak anlamlı değildi (Tablo 4). Görme işlevi ile kişiler arası ilişkiler arasında çok

Tablo 3. Öz bakım işlevselliği ile hareket işlevselliği, prematüre sorunları ve anne eğitim durumu arasındaki ilişki.

\begin{tabular}{|c|c|c|c|c|}
\hline & & Ciddi düzey (n) & Hafif-orta düzey (n) & Sorun yok (n) \\
\hline \multirow[b]{2}{*}{$\mathrm{EMR}^{* *}$} & Var & 7 & 6 & 1 \\
\hline & Yok & 5 & 23 & 16 \\
\hline \multirow{2}{*}{ NEK** } & Var & 7 & 9 & 2 \\
\hline & Yok & 5 & 20 & 15 \\
\hline \multirow[t]{2}{*}{ Serebral palsi* } & Var & 6 & 2 & 0 \\
\hline & Yok & 6 & 27 & 17 \\
\hline \multirow{2}{*}{$\begin{array}{l}\text { Anne } \\
\text { eğitim durumu** }\end{array}$} & Ev hanımı & 12 & 24 & 10 \\
\hline & Çalışmıyor & 0 & 5 & 7 \\
\hline \multirow{3}{*}{$\begin{array}{l}\text { Hareket } \\
\text { işlevselliği* }\end{array}$} & Ciddi & 8 & 8 & 1 \\
\hline & Hafif-orta & 4 & 14 & 5 \\
\hline & Sorun yok & 0 & 7 & 11 \\
\hline
\end{tabular}


kuvvetli bir ilişki saptandı. Kendine ait odası olan olgularımızın kişiler arası ilişkilerinin anlamlı olarak daha iyi düzeyde olduğu tespit edildi. Annenin ve babanın eğitim durumu ile kişiler arası ilişkiler arasında anlamlı bir ilişki saptanmadı. Aynı şekilde kreşe gidip gitmeme ile de kişiler arası ilişkiler arasında anlamlı bir ilişki tespit edilmedi. Kişiler arası ilişkilerinde ciddi düzeyde sorun yaşanan 8 olgumuzun 4'ü özel eğitim almıyordu. Tüm olgular incelendiğinde ise bu alanda sorun saptanan 35 olgunun 30'u özel eğitimden faydalanmıyordu.

\section{Oyun ve boş zaman}

Serebral palsisi olan 8 olgumuzun ise hepsinin oyun ve boş zaman etkinliklerine katılımında sorun olduğu tespit edilirken serebral palsisi olmayan 50 olgumuzun sadece $\% 4$ 'ünde ciddi düzeyde sorun saptandı ve aralarındaki ilişki yüksek düzeyde anlamlı idi ( $p=0,0001)$. Hareket işlevselliği ve görme işlevlerinde sorun saptanan olguların oyun ve boş zaman etkinliklerine katılımında ciddi düzeyde sorun yaşadıkları görüldü. Olgularımızın kendine ait odasının olmasının oyun ve boş zaman etkinliklerine katılımı anlamlı olarak etkilediği saptandı. Aynı şekilde anne ve babanın öğrenim durumunun oyun etkinliklerine katılımı anlamlı olarak etkilediği görüldü. Çalışan annesi olan olgularımızın oyun ve boş zaman etkinliklerine katılımda daha az sorun yaşadığı bulundu. Bakıcısı olan olgularımızın oyun ve boş zaman etkinliklerine katılımda daha iyi durumda oldukları görüldü $(p=0,03)$.

\section{Öğrenme ve problem çözme işlevleri}

Olgularımızın baba ve anne yaşı arttıkça öğrenme ve problem çözme işlevselliğinde sorun yaşama oranlarının arttığı görülmesine rağmen aradaki ilişki anlamlı bulunmadı. Çalışan annesi olanların öğrenme ve problem çözebilme becerilerinde daha hafif sorunlar yaşadığı tespit edildi (Tablo 5). Anne ve babanın öğrenim durumunun ise olgularımızın öğrenme işlevselliğini etkilemediği bulundu. Buna karşın bakıcısı olan olgularımızın problem çözebilme işlevselliğinin daha sorunsuz olduğu görüldü $(p=0,033)$. Öğrenme ve problem çözme işlevselliğinde ciddi sorun yaşayan 18 olgunun 13'ünün özel eğitim desteği almadığı tespit edildi. Bu alanda sorun yaşayan toplam 56 hastanın ise sadece 5 'inin özel eğitim aldığı saptandı.

\section{MOTOR BECERILER-INCE VE KABA HAREKET}

Prematüre sorunları ile karşılaşma ve hareket işlevselliği arasındaki ilişki Tablo 6'da belirtilmiştir. Menenjit geçiren olgularımızın hareket işlevselliğinde daha ciddi sorunlar yaşamalarına

Tablo 4. Olgularımızın prematüre sorunları ile kişiler arası ilişkileri arasındaki ilişki.

\begin{tabular}{|c|c|c|c|c|c|}
\hline & & Ciddi düzey (n) & Hafif-orta düzey (n) & Sorun yok (n) & $p$ \\
\hline \multirow{2}{*}{ Koryoamnionit } & Var & 3 & 2 & 0 & \multirow{2}{*}{0,005} \\
\hline & Yok & 5 & 25 & 23 & \\
\hline \multirow{2}{*}{ Sepsis } & Var & 5 & 17 & 7 & \multirow{2}{*}{0,04} \\
\hline & Yok & 3 & 10 & 16 & \\
\hline \multirow{2}{*}{ Steroid tedavisi } & Alan & 4 & 12 & 3 & \multirow[t]{2}{*}{0,03} \\
\hline & Almayan & 4 & 15 & 20 & \\
\hline \multirow{2}{*}{ BPD } & Var & 5 & 15 & 4 & \multirow{2}{*}{0,01} \\
\hline & Yok & 3 & 12 & 19 & \\
\hline \multirow{2}{*}{ Serebral palsi } & Var & 6 & 2 & 0 & \multirow{2}{*}{0,0001} \\
\hline & Yok & 2 & 25 & 23 & \\
\hline
\end{tabular}

BPD: Bronkopulmoner displazi, n: Olgu sayısı

Tablo 5. Öğrenme ve problem çözme işlevselliği ile annenin çalışma durumu arasındaki ilişki.

Öğrenme ve problem çözme işlevselliği (n)

\begin{tabular}{lccc} 
& Ciddi düzey & Hafif-orta düzey & Sorun yok \\
\cline { 2 - 4 } Ev hanımı & 18 & 27 & 1 \\
\hline Çalışıyor & 0 & 11 & 1 \\
\hline $\mathrm{p}=0,02$ (Ki-Kare), n: Olgu sayısı & & &
\end{tabular}


Tablo 6. Hareket işlevselliği ile prematüre sorunları arasındaki ilişki.

\begin{tabular}{|c|c|c|c|c|c|c|c|}
\hline & & \multicolumn{3}{|c|}{ İnce hareket (n) } & \multicolumn{3}{|c|}{ Kaba hareket (n) } \\
\hline & & Ciddi & Hafif-orta & Sorun yok & Ciddi & Hafif-orta & Sorun yok \\
\hline \multirow{2}{*}{ EMR* $^{*}$} & Var & 7 & 5 & 2 & 6 & 7 & 1 \\
\hline & Yok & 6 & 21 & 16 & 5 & 25 & 14 \\
\hline \multirow{2}{*}{ Koryoamnionit* } & Var & 5 & 0 & 0 & 3 & 2 & 0 \\
\hline & Yok & 8 & 26 & 19 & 8 & 30 & 15 \\
\hline \multirow{2}{*}{$\mathbf{P V L}^{*}$} & Var & 3 & 0 & 2 & 3 & 0 & 2 \\
\hline & Yok & 10 & 26 & 17 & 8 & 32 & 13 \\
\hline \multirow{2}{*}{ Menenjit } & Var & 2 & 3 & 1 & 1 & 4 & 1 \\
\hline & Yok & 11 & 23 & 18 & 10 & 28 & 14 \\
\hline \multirow{2}{*}{ GM-iVK } & Var & 8 & 8 & 7 & 5 & 10 & 8 \\
\hline & Yok & 5 & 18 & 12 & 6 & 22 & 7 \\
\hline \multirow{2}{*}{ Sepsis } & Var & 9 & 10 & 9 & 7 & 15 & 7 \\
\hline & Yok & 4 & 16 & 9 & 4 & 7 & 18 \\
\hline \multirow{2}{*}{ Steroid } & Var & 6 & 8 & 5 & 3 & 13 & 3 \\
\hline & Yok & 7 & 18 & 14 & 8 & 19 & 12 \\
\hline
\end{tabular}

rağmen aralarındaki ilişki anlamlı değildi. Steroid tedavisi alan 19 olgunun 14 'ünde ince hareket işlevselliğinde,16'sında ise kaba hareket işlevselliğinde sorun saptandı. Evre-3 ve üzeri ROP olan olgularımızın hepsinde ince ve kaba hareket işlevselliğinde sorun yaşanırken, ROP olmayan olgularımızın sadece 2'sinde bu alanda sorun saptandı ve aralarındaki ilişki anlamlı bulundu. Olgularımızın görme işlevleri ile hareket işlevselliği arasında çok anlamlı bir ilişki saptandı $(p=0,0001)$. Annenin eğitim durumunun olgularımızın hareket işlevselliğini anlamlı olarak etkilediği görüldü.

Kas gücü ve tonusunun hareket işlevselliğini çok anlamlı bir şekilde etkilediği görülürken eklem işlevlerinin özellikle ince hareket işlevselliğini etkilediği saptandı.Tüm olgular içinde 2'sinin kronik ağrısı mevcut idi ve bu iki olgunun da hareket işlevselliğinde sorun saptandı.

\section{Uyumlu Davranış Bileşkesi}

Olgularımızın uyumlu davranış bileşke düzeyleri belirlendi (Tablo 7). Buna göre tüm olgularımızın \%22,4'ü (13 olgu) düşük seviyede saptanırken, \%53,4'ü ortalamanın altında bulundu, 14 olgunun ise uyumlu davranış bileşke skorları normal tespit edildi. Olgularımızın yoğun bakım ünitesinde yatış süreleri uzadıkça uyumlu davranış sorunlarının anlamlı olarak arttığı saptandı $(p=0,048)$. Gestasyon yaşı, doğum ağırlığı ile bu şekilde bir ilişki saptanmadı. NEK, RDS, ROP, sepsis, posthemorajik hidrosefali, BPD ile ilişki istatistiksel olarak anlamsızdı. Menenjit geçiren olgularımızın ise bileşke skorlarının daha düşük olmasına rağmen aralarındaki ilişki anlamlı bulunmadı.

Steroid tedavisi alan hastalarımızın uyumlu davranış bileşke skorları anlamlı olarak daha düşük tespit edildi $(p=0,05)$. Serebral palsi ile bileşke düzeyleri arasında çok anlamlı bir ilişki tespit edildi $(p=0,0001)$.

Annenin eğitim durumunun olgularımızın uyumlu davranış düzeylerini anlamlı olarak etkilediği görülürken, baba eğitim durumunun uyumlu davranış düzeylerini etkilemediği tespit edildi ( $p=0,001$ ). Aynı şekilde annenin çalışma durumunun da uyumlu davranış bileşke düzeylerini etkilediği görüldü $(p=0,001)$. Bakıcısı olanların uyumlu davranış bileşke skorlarının anlamlı olarak daha yüksek olduğu görüldü $(p=0,003)$. Kendine ait odası olan 15 olgunun 9'unun uyumlu davranış bileşke düzeyi normal iken, odası olmayan 43 olgunun sadece 5 'inin normal olduğu tespit edildi ( $p=0,0001$ ). Görme işlevselliğinin olgularımızın uyumlu davranış bileşke skorlarını çok anlamlı bir şekilde etkilediği saptandı $(p=0,0001)$. Kronik ağrının uyumlu davranış bileşke düzeyini anlamlı olarak etkilemediği belirlendi. Uyumlu davranış bileşke düzeyi düşük olan 13 olgudan 8'inin özel eğitim desteğinden faydalanmadığı tespit edildi. 
Tablo 7. Uyumlu olmayan davranışlar ile prematüre sorunları arasındaki ilişki.

\begin{tabular}{|c|c|c|c|c|}
\hline & & Normal (n) & Hafif-orta (n) & Ciddi (n) \\
\hline \multirow[b]{2}{*}{ Koryoamnionit* } & Var & 1 & 2 & 2 \\
\hline & Yok & 41 & 11 & 1 \\
\hline \multirow{2}{*}{ EMR } & Var & 9 & 3 & 2 \\
\hline & Yok & 33 & 10 & 1 \\
\hline \multirow[t]{2}{*}{ GM-iVK** } & Var & 11 & 10 & 2 \\
\hline & Yok & 31 & 3 & 1 \\
\hline \multirow{2}{*}{ Steroid tedavisi } & Almış & 13 & 5 & 1 \\
\hline & Almamış & 29 & 8 & 2 \\
\hline \multirow{2}{*}{ Hidrosefali** } & Var & 0 & 1 & 1 \\
\hline & Yok & 42 & 12 & 2 \\
\hline \multirow{2}{*}{ RDS } & Var & 13 & 5 & 2 \\
\hline & Yok & 29 & 8 & 1 \\
\hline \multirow{2}{*}{ NEK** } & Var & 12 & 3 & 3 \\
\hline & Yok & 30 & 10 & 0 \\
\hline \multirow{2}{*}{ PVL } & Var & 4 & 1 & 0 \\
\hline & Yok & 38 & 12 & 3 \\
\hline \multirow{2}{*}{ ROP** } & Var & 22 & 7 & 3 \\
\hline & Yok & 20 & 6 & 0 \\
\hline \multirow{2}{*}{ BPD } & Var & 16 & 6 & 2 \\
\hline & Yok & 26 & 7 & 1 \\
\hline \multirow{2}{*}{ Sepsis } & Var & 18 & 8 & 3 \\
\hline & Yok & 24 & 5 & 0 \\
\hline
\end{tabular}

Tüm olgular içinde ise uyumlu davranış bileşke skorları ortalamanın altında olan 44 olgudan 39'unun özel eğitim desteğinden faydalanmadığı saptandı.

\section{Uyumlu Olmayan Davranışlar}

Olgularımızın \%72,4'ünün (42 olgu) uyumlu olmayan davranışlarda sorun göstermediği 13 olgunun ise hafif-orta düzeyde sorun yaşadığı, 3 olgunun ise ciddi düzeyde sorun yaşadığı saptandı (Şekil 1). Yoğun bakım yatış süreleri uzun olan olgularımız klinik olarak daha anlamlı uyumlu olmayan davranış gösterdikleri tespit edildi $(p=0,005)$. Doğum ağırlığı, gestasyon yaşı ile uyumlu olmayan davranışlar arasında bu şekilde bir ilişki saptanmadı. Serebral palsisi olan olgularımızın anlamlı olarak daha fazla oranda uyumlu olmayan davranış sergiledikleri tespit edildi (Tablo 7). ICF-CY sınıflamasında belirlenen alanlarda sorun yaşama oranları ile uyumlu olmayan davranışlar arasındaki ilişki Tablo 8'de özetlenmiştir.

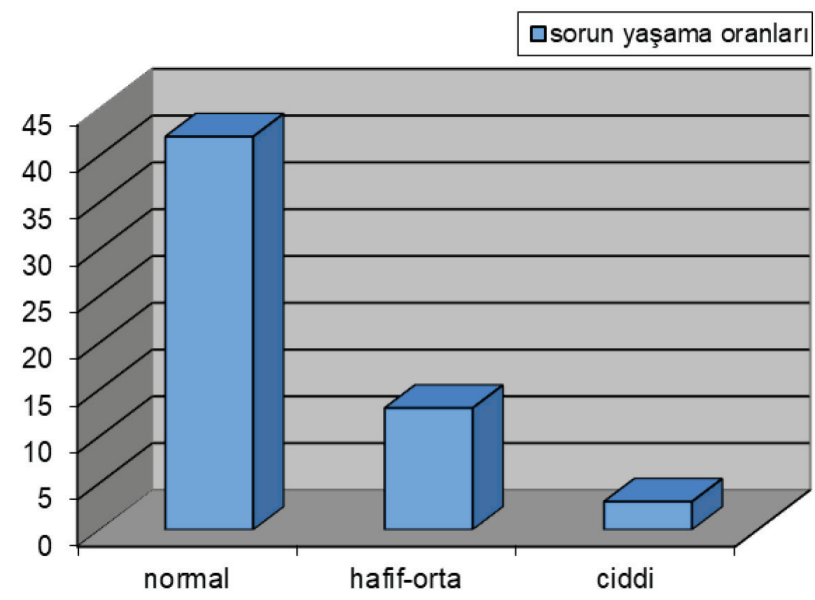

Şekil 1. Olgularımızın uyumlu olmayan davranışlarda sorun yaşama oranları. 
Tablo 8. ICF-CY sınıflamasında belirlenen alanlarda sorun yaşama oranları ile uyumlu olmayan davranışlar arasındaki ilişki.

\begin{tabular}{|c|c|c|c|c|c|}
\hline & & \multicolumn{4}{|c|}{ Uyumlu olmayan davranışlardaki sorun düzeyi (n) } \\
\hline & & Sorun yok & Hafif-orta & Ciddi & $p$ \\
\hline \multirow{3}{*}{ İletişim işlevselliği** } & Ciddi & 6 & 3 & 3 & \multirow{3}{*}{0,005} \\
\hline & Hafif-orta & 30 & 6 & 0 & \\
\hline & Sorun yok & 6 & 4 & 0 & \\
\hline \multirow{3}{*}{ Günlük yaşam becerileri* } & Ciddi & 3 & 1 & 3 & \multirow{3}{*}{0,0001} \\
\hline & Hafif-orta & 17 & 7 & 0 & \\
\hline & Sorun yok & 22 & 5 & 0 & \\
\hline \multirow{3}{*}{ Sosyalleşme işlevselliği** } & Ciddi & 5 & 3 & 3 & \multirow{3}{*}{0,004} \\
\hline & Hafif-orta & 28 & 6 & 0 & \\
\hline & Sorun yok & 9 & 4 & 0 & \\
\hline \multirow{3}{*}{ Hareket işlevselliği* } & Ciddi & 7 & 7 & 3 & \multirow{3}{*}{0,001} \\
\hline & Hafif-orta & 21 & 2 & 0 & \\
\hline & Sorun yok & 14 & 4 & 0 & \\
\hline
\end{tabular}

\section{TARTIŞMA}

Son 25-30 yılda aşırı düşük doğum ağırlı̆ı ile doğan prematürelerin yaşatılma oranlarının artması, uzun süreli izlemde yaşam kalitesini değişik düzeylerde etkileyerek bazı gelişimsel sorunları da beraberinde getirmiştir. Prematüre bebeklerin uzun dönem izlem sonuçlarını inceleyen birçok çalışmada doğum ağırlığı ve gebelik haftası düşük olanların gelişimsel sorunlarının daha fazla olduğu vurgulanmıştır (6). Çalışmamızda hastalarımızın iletişim işlevselliği, günlük yaşam becerilerine katılımı, sosyalleşme işlevselliği ile gebelik haftası ve doğum ağırlığı arasında anlamlı bir ilişki saptanmadı.

Düşük doğum ağırlıklı (DDA) ve 4 yaşına gelmiş çocuklarda yapılan İskoçya kohort çalışmasında tüm olguların \%47'sinde iletişim işlevselliğinde sorun olduğu tespit edilmiştir (7). ADDA ve DDA bebeklerin incelendiği bir çalışmada ise iletişim işlevselliğinde sorun yaşama oranları \%5-22 bulunmuştur (8). Bizim çalışmamızdaki olgular incelendiğinde iletişim alanında 12 olgunun $(\% 20,7)$ ciddi düzeyde, 36 olgunun $(\% 62,1)$ hafif-orta düzeyde sorun yaşadığı tespit edildi. Olgularımızın \%17,2'sinin ise bu alanda sorun yaşamadığı belirlendi. Avustralya'da Betty ve ark. tarafından yapılan çalışmada, 227 prematüre $(<30 \mathrm{GH}$ ve $<1250 \mathrm{~g}) 5$ yaşında incelenmiş ve annenin eğitim düzeyinin bu çocukların iletişim işlevselliğini etkilediği rapor edilmiştir (9). Bizim çalışmamızda da annenin eğitim durumu ile alıcı dil işlevselliği arasında anlamlı bir ilişki saptandı.

Çekirdek aile olmayan 4 hastadan hepsinin alıcı dil işlevlerinin normal olduğu görülürken çekirdek ailesi olanların $\% 24,1$ 'inde alıı dil işlevlerinde sorun olduğu tespit edildi. Bu da bize kalabalık ailelerde yaşamanın alıcı dil işlevselliğini olumlu olarak etkilediğini göstermektedir.

Çalışmamızda 12 prematüre çocukta $(\% 20,7)$ anlatım dili işlevselliğinde ciddi düzeyde sorun saptanırken $30^{\prime}$ unda $(\% 51,7)$ hafif-orta düzeyde gerilik vardı. Bu durum hastalarımızın anlatım dili işlevselliğinde alıc dil işlevselliğine oranla daha ciddi sorun olduğunu ortaya koymaktadır.

Birçok çalışmada GM-IVK, BPD ve koryoamnionit ile iletişim işlevselliği arasında anlamlı bir ilişki saptanmıştır (10-12). Çalışmamızda EMR, koryoamnionit, NEK ile anlatım dili işlevselliği arasında anlamlı bir ilişki saptanırken, GM-IVK, PVL, RDS, BPD ve steroid tedavisi ile anlatım dili işlevselliği arasında anlamlı bir ilişki saptanmadı. GM-IVK ile iletişim işlevselliği arasında ilişki olmaması olgularımızda ileri evre kanama oranının düşük olmasına bağlı olabileceği düşünüldü. Voorman JM ve ark. 110 serebral palsili olguyu inceledikleri bir çalışmada serebral palsi şiddeti arttıkça iletişim işlevselliğinde daha ciddi sorunlar olduğunu rapor etmişlerdir (13). Bizim çalışmamızda ise serebral palsisi olan hastaların anlatım dili işlevselliğinde anlamlı olarak ciddi sorunlar yaşadıkları görülmüş, serebral palsi şiddeti arttıkça sorun yaşama oranlarının da paralel olarak arttığı tespit edilmiştir.

Çalışmamızda annesi çalışan bebeklerin iletişim işlevselliği çalışmayan anne bebeklerine göre anlamlı olarak daha iyi bulunmuştur. Aynı şekilde kendisine ait bir odası ve oyun odası olanların olmayanlara göre bu alandaki durumlarının daha iyi 
olduğu saptanmıştır. Bu bulgular iyi sosyoekonomik düzeyin etkisine bağlanmıştır.

Olgularımızın günlük yaşam becerilerini yerine getirebilmede 7'sinin ciddi düzeyde, 24'ünün ise hafif-orta düzeyde sorunları olduğu görüldü. Buna karşılık \%46,6 prematüre çocuğun günlük yaşam becerilerini yerine getirebilme kapasitesinde sorun yoktu. Hack ve ark. yaptığı çalışmada 750 gram altında doğan prematürelerin 8 yaşındaki değerlendirmesinde olguların \%27'sinin günlük yaşam becerilerine katılımda ciddi düzeyde yetiyitimi olduğunu vurgulanmıştır (14). Msall ve ark. çalışmasında ise 148 ADDA bebeğin 4,5 yaşında \%4 sıklıkta basit günlük yaşam becerilerinde ciddi sorun yaşadıklarını rapor etmiştir (15). Aynı çalışmada bu sorunların majör belirleyicilerinin majör nörogelişimsel bozukluklar ve ROP olduğu ifade edilmiştir. Bir başka çalışmada ağır BPD'nin preterm bebeklerin ileri dönemde günlük yaşam becerilerine katılımı anlamlı olarak etkilediği gösterilmiştir (16). Bizim çalışmamızda EMR ve PVL saptanan olgularda günlük yaşam becerilerine katılımda ciddi sorunlar yaşanırken, koryoamnionit, GM-IVK, RDS, ROP, BPD, sepsis ve posthemorajik hidrosefali tanımlanan olgularda anlamlı ilişki saptanmamıştır. IVK ve ROP ile günlük yaşam becerilerine katılımdaki sorun düzeyleri arasında ilişki olmaması olgularımızda ileri evre kanama ve ROP oranlarının düşük olmasına bağlanmıştır.

Olgularımızda serebral palsi ile öz bakım işlevselliği ve ev yaşamı etkinliklerine katılım arasında çok anlamlı bir ilişki tespit edildi. Aynı şekilde hareket işlevselliğinde sorun yaşayan olguların öz bakım işlevselliğinde anlamlı düzeyde ve yüksek oranda sorun yaşadıkları belirlendi. Palta ve ark. yaptığı çalışmada $<1500$ gr prematüre çocuklar 5 yaşında incelenmiş ve öz bakım işlevselliğinde serebral palsisi olmayanların \%5,2'sinde sorun varken, serebral palsisi olanların \%57'sinde sorun yaşandığı belirlenmiştir (17).

Düşük sosyoekonomik düzeyin prematüre bebeklerin uzun dönem sonuçlarını olumsuz etkilediği bilinmektedir. Bu etki birçok çalışmada gösterilmiştir $(18,19)$. Bizim çalışmamızda annenin eğitim durumunun olgularımızın günlük yaşam becerilerine katılımını anlamlı bir şekilde etkilediği gösterilmiş, aynı şekilde kendine ait odası olan olgularımızın öz bakım işlevselliğinde ve evdeki yaşam becerilerine katılımda daha iyi durumda oldukları görülmüştür. Çalışmamızda bakıcısı olan çocukların öz bakım işlevselliğinde anlamlı olarak daha az sorun yaşadığı saptanmıştır. Buradan yola çıkarak annelerin ADDA bebeklerine karşı çok hassas ve korumacı tutumunun olgularımızın öz bakım işlevselliğini olumsuz etkilediği sonucuna varılmıştır.

Grunau ve ark. yapmış olduğu bir çalışmada ADDA ile doğan çocukların çeşitli atletik sporlara ve okuldaki derslere katılımda, romantik ilişkilerde, iş ortamında kendini ispat etmede öz güvenlerinin az olduğu rapor edilmiştir (20). Çalışmamızda 11 prematüre çocuğun (\%19) sosyalleşme kapasitesinde ciddi düzeyde sorun yaşadığı saptanırken, 34 olgunun $(\% 58,6)$ hafif-orta düzeyde sorun yaşadığı, 13'ünün ise sosyalleşme kapasitesinde sorunu olmadığı görülmüştür.
Olgularımızın kişiler arası ilişkilerde \%13,8'inin ciddi düzeyde sorun yaşadığı tespit edilmiştir. Hamilton ve ark. çalışmasında 156 ADDA prematürenin 8 yaşına geldiğinde majör nörogelişimsel sorunu olanların (\%15 serebral palsi, \%10 zeka geriliği, \%10 körlük) \%62'sinin kiş̧iler arası ilişkilerde sorunu olduğu saptanmıştır (21). Bir başka çalışmada serebral palsisi olanların \%32'sinin sosyalleşme işlevselliğinde sorun olduğu, serebral palsisi olmayanların \%7,6 sıklıkta sorun yaşadığı bildirilmiştir. Bizim çalışmamızda da olgularımızın görme işlevleri ile kiş̧iler arası ilişkilerde, oyun ve boş zaman etkinliklerine katılımında sorun yaşama oranları arasında çok kuvvetli bir ilişki saptandı. Aynı şekilde serebral palsili çocukların kişiler arası ilişkilerde, oyun ve boş zaman etkinliklerine katılımda daha ciddi düzeyde sorun yaşadıkları saptanmıştır.

Araştırmamızda tüm olgularımızın öğrenme ve problem çözme işlevleri incelendiğinde sadece 2 olgumuzda bu alanda sorun saptanmadığı belirlendi. 18 hastada $(\% 31,1)$ ciddi düzeyde sorun varken 38 olguda $(\% 65,5)$ hafif-orta düzeyde sorun olduğu belirlenmiştir. İngiltere ve İrlanda'da 1995 yılında doğan 26 gebelik haftasından küçük prematüreler 30 . ayda incelenmiş ve \%22'sinin ciddi, \%58'inin ise hafif-orta düzeyde öğrenme sorunları olduğu bildirilmiştir (22). Bir başka çalışmada ise 1500 gram altında doğan prematüre çocukların 11 yaşındaki değerlendirmesinde öğrenme işlevselliğinde erkeklerde daha ciddi sorun olduğu gözlenmiştir (23). Bizim çalışmamızda ise her iki cinsiyet arasında fark saptanmamıştır.

Çalışmamızda öğrenme ve problem çözme işlevselliği ile koryoamnionit, EMR arasında anlamlı bir ilişki bulunmuştur. Aşırı düşük doğum ağırlıklı prematürelerin uzun dönem sonuçlarının incelendiği 1151 olguda BPD nedeni ile postnatal steroid alan ve annesinde koryoamnionit olanların öğrenme işlevselliğinin anlamlı olarak daha düşük olduğu saptanmıştır (24). Bizim çalışmamızda ise steroid tedavisi almanın olgularımızın öğrenme işlevselliğini etkilemediği görülmüştür.

Annesi çalışan olgularımızın öğrenme ve problem çözme işlevselliğinin anlamlı olarak daha iyi olduğu saptanırken bunun nedeni çalışan annelerin çocukları ile kısıtlı bir zaman da olsa daha fazla ilgilenmelerine, daha değerli zaman geçirmelerine bağlanmıştır.

Çalışmamızda olgularımızın hareket işlevselliğinin günlük yaşam becerilerine katılımlarını ve sosyalleşme işlevselliğini çok anlamlı olarak etkilediği gösterilmiştir.

Aşırı düşük doğum ağırlıklı çocukların davranışsal sorunlarının normal yaşıtlarına göre daha fazla olduğu değişik çalışmalarda gösterilmiştir. Bhutta ve ark. tarafından yayınlanan bir metaanaliz çalışmasında, son 20 yıl içindeki 16 çalışma incelenmiş, çalışmaların \%81'inde prematüre doğan çocuklarda okul çağına gelindiğinde, içe dönük ve dışa dönük davranış sorunlarının artmış olduğu saptanmıştır (25). İlişki ve iletişim kurma sorunları, kendine güvensizlik, içe dönüklük, kaygı bozukluğu, depresyon ve sosyal yetilerde sorunlar, ADDA çocuklarda normal doğan çocuklara göre daha sık olarak bildirilmektedir (26). ÇaIışmamızda olgularımızın \%72,4'ünün (42 olgu) uyumlu olma- 
yan davranışlarda sorun yaşamadığı tespit edildi. 13 olgunun hafif-orta düzeyde sorun yaşadığı, 3 olgunun ise ciddi düzeyde sorun yaşadığı saptandı. Çalışmalarda GM-iVK ve PVL'nin davranış sorunlarını arttırdığı bildirilmiştir (27). Bizim çalışmamızda olgularımızın koryoamnionitli anne bebeği olmasının ve GM-iVK geçirmesinin uyumlu olmayan davranışlarını anlamlı bir şekilde etkilediği görülmüştür. Buna karşılık PVL, RDS, BPD, sepsis, menenjit, NEK, ROP ve steroid tedavisi ile ilişki saptanmamıştır. Posthemorajik hidrosefali ve serebral palsi ile uyumlu olmayan davranış düzeyi arasında çok kuvvetli bir ilişki görülmüştür. Yoğun bakım ünitesinde uzun yatış; uyumlu olmayan davranışı istatistiksel anlamlı düzeyde etkilemiştir.

Aşırı düşük doğum ağırlıklı çocuklar okul öncesi dönemde değişik alanlarda sıklıkla sorun yaşamakta ve özel eğitim desteğine ihtiyaç duymaktadırlar. Bir çalışmada 1000 gram altında doğanlarda bu oran \%26 olarak bulunmuştur (28). Bizim çalışmamızda olgularımızın Vineland Uyum ve Davranış Ölçeğine göre uyumlu davranış bileşke düzeyleri tanımlanmış, bu düzeye göre özel eğitim gereksinimleri belirlenmiştir. Buna göre çalışmamızda, olgularımızın \%22,4'ünün yüksek seviyede özel eğitim ihtiyacı olduğu görülmüştür. Özellikle ciddi düzeyde sorunu olanlar incelendiğinde bu olguların yoğun bakım ünitesinde daha uzun süre yatan, GM-iVK ve PVL olan prematüreler olduğu görülmüştür. Steroid tedavisinin prematüre çocukların uzun dönem sonuçlarını olumsuz yönde etkilediği birçok çalışmada gösterilmiştir (29). Çalışmamızda da steroid tedavisi alanların uyumlu davranış bileşke skorları daha düşük saptanmıştır. Serebral palsisi olan 8 olgunun hepsinin de uyumlu davranış bileşke düzeyi anormaldi ve aralarındaki ilişki anlamlı bulundu. Annenin eğitim durumunun olgularımızın uyumlu davranış düzeylerini anlamlı olarak etkilediği görülürken, baba öğrenim durumunun bu etkiyi yapmadığı tespit edilmiştir. Anne ve babanın düşük öğrenim durumunun ADDA çocukların birçok işlevselliğini kötü yönde etkilediği çalışmalarda da gösterilmiştir $(18,19)$.

Yüksek seviyede özel eğitim gerekliliği olan 13 olgudan 8'inin özel eğitim desteğinden faydalanmadığı tespit edilmiştir. Özel eğitim desteğinden faydalanmayan 8 olgunun sosyodemografik özellikleri incelendiğinde olguların annelerinin eğitim seviyesinin ve sosyoekonomik düzeylerinin anlamlı olarak düşük olduğu saptanmıştır. Çalışmanın sonunda sorun yaşayan prematüre çocuklar gerekli bölümlere yönlendirilmiştir.

Sonuç olarak ADDA prematüreler başta olmak üzere tüm prematüreler, kısa ve uzun dönem izleminde sorunlar yaşayan riskli yenidoğanlardır. Prematürelerin uzun süreli izlemi bir halk sağlığı sorunudur. Erken dönemde yaşadığı sorunlar; uzun dönemde karşımıza dil, iletişim, zihinsel aktivite ve hareket alanlarında sorun olarak çıkmaktadır. Bu çocukların ilk üç yaşta yakın izlemi, okul öncesi-okul döneminde de tekrar değerlendirilmesi, gereksinimi olanların rehabilitasyon programları ile desteklenmesi çok önemlidir. Prematüre doğmuş ergenler adölesan dönemde de çevre, aile ve psikososyal faktörlerden etkilendiğinden bu bakış açısından değerlendirilmeli ve desteklenmelidir.
Teşekkür: Bu çalışmada bize büyük desteği nedeniyle Ankara Üniversitesi Tıp Fakültesi Gelişimsel Pediatri Bilim Dalı́nın değerli öğretim üyesi Sayın Prof. Dr. İlgi Ertem ve ekibine şükran ve teşekkürlerimizi sunarız.

Etik Komite Onayı: Etik kurul onayı İstanbul Bakırköy Kadın Doğum ve Çocuk Hastalıkları Eğitim ve Araştırma Hastanesi Etik Kurulundan alınmıştır (2009/208).

\section{Hakem Değerlendirmesi: Dış bağımsız.}

Yazar Katkıları: Çalışma Konsepti/Tasarımı - B.U.; Materyal: B.U.; Veri Toplama - B.U., S.K.; Veri Analizi/Yorumlama - B.U.; Yazma - B.U.; S.K.; Son Onay ve Sorumluluk - B.U., S.K.

Çıkar Çatışması: Yazarlar çıkar çatışması bildirmemişlerdir.

Finansal Destek: Yazarlar bu çalışmada finansal destek almadıklarını beyan etmişlerdir.

Acknowledgements: We would like to express our gratitude and appreciation to dear Professor Dr. Ilgi Ertem an her team from Ankara University Faculty of Medicine, Department of Developmental Pediatrics for their great support and help in this study.

Ethics Committee Approval: Ethics committee approval was obtained from Istanbul Bakırköy Gynecology and Pediatrics Training and Research Hospital (2009/208).

Peer-review: Externally peer-reviewed.

Author Contributions: Conception/Design of Study - B.U.; Materials - B.U.; Data Collection and/or Processing - B.U., S.K.; Analysis and/or Interpretation - B.U.; Drafting Manuscript - B.U., S.K.; Final Approval and Accountability - B.U., S.K.

Conflict of Interest: The authors have no conflict of interest to declare.

Financial Disclosure: The authors declared that this study has received no financial support

\section{KAYNAKLAR/REFERENCES}

1. Chung EH, Chou J, Brown KA. Neurodevelopmental outcomes of preterm infants: a recent literature review. Transl Pediatr 2020; 9 (Suppl 1): 3-8.

2. World Health Organization: International Classification of Functioning, Disability and Health, Geneva, WHO, 2001.

3. Sparrow SS, Cicchetti DV, Balla DA. Vineland adaptive behavior scales 2nd ed. AGS Publishing; Circle Pines, MN: 2005.

4. Rosenbaum P, Saiga S, Szatmari P, Hoult L. Vineland adaptive behavior scales as a summary of functional outcome of extremely low-birth weight children. Dev Med Child Neurol 1995; 37: 577-86. [CrossRef]

5. De Battista AM, Huffman LC, Cooper B, Alkon A, Kennedy CM, Weiss SJ. Adaptive Behavior Trajectories in Children Born Prematurely: The infuence of biologic and social risk factors over the first few years of life. Ann Pediatr Child Health 2016; 4(2): 1101.

6. Pascal A, Govaert P, Oostra A, Naulaers G, Ortibus E, Van Den Broeck C. Neurodevelopmental outcome in very preterm and very-low birthweight infants born over the past decade: a meta-analytic review. Dev Med Child Neurol 2018; 60: 342-55. [CrossRef] 
7. The Scottish low birthweight study: II. Language attainment, cognitive status, and behavioural problems. Arch Dis Child 1992; 67: 682-6. [CrossRef]

8. Sajaniemi N, Hakamies-Blomqvistb N, Katainenc S, Wendta L. Early cognitive and behavioral predictors of later performance: a follow-up study of ELBW children from ages 2 to 4 . Early Child Res $Q$ 2001; 16: 343-61. [CrossRef]

9. Vohr BR, Msall ME. Neuropsychological and functional outcomes of very low birth weight infants. Seminars in perinatology 1997; 21: 202-20. [CrossRef]

10. Chen PS, Jeng SF, Tsou KI. Developmental function of ver$y$-low-birth-weight infants and full-term infants in early childhood. J Formos Med Assoc 2004; 103: 23-31.

11. Sullivan MC, Msall ME. Functional performance of preterm children at age 4. J Pediatr Nurs 2007; 22: 297-309. [CrossRef]

12. Short EJ, Klein NK, Lewis BA, Fulton S, Eisengart S, Kercsmar C, et al. Cognitive and academic consequences of bronchopulmonary dysplasia and very low birth weight: 8-year-old outcomes. Pediatrics 2003; 112: e359.

13. Voorman JM, Dallmeijer AJ, Van Eck M, Schuengel C, Becher JG. Social functioning and communication in children with cerebral palsy: association with disease characteristics and personal and environmental factors. Dev Med Child Neurol 2010; 52: 441-7. [CrossRef]

14. Hack M, Friedman $H$, Fanaroff AA. Outcomes of extremely low birth weight infants between 1982-1988. N Eng J Med 1989; 321: 1642-7. [CrossRef]

15. Msall ME, Rogers BT, Buck GM, Mallen S, Catanzaro NL, Duffy LC. Functional status of extremely preterm infants at kindergarten entry. Dev Med Child Neurol 1993; 35: 312-20. [CrossRef]

16. Moore GP, Lemyre B, Barrowman N, Daboval T. Neurodevelopmental outcomes at 4 to 8 years of children born at 22 to 25 weeks' gestational age: a meta-analysis. JAMA Pediatr 2013; 167: 967-74. [CrossRef]

17. Palta M, Sadek-Badawi M, Evans M, Weinstein MR, McGuinnes G. Functional assessment of a multicenter very low-birth-weight cohort at age 5 years. Newborn Lung Project. Arch Pediatr Adolesc Med 2000; 154: 23-30.

18. Dieterich SE, Hebert HM, Landry SH, Swank PR, Smith KE. Maternal and child characteristics that influence the growth of daily living skills from infancy to school age in preterm and term children. Early Education and Development 2004; 15: 283-304. [CrossRef]
19. Delmas O, Garcia P, Bernard V, Fabre M, Vialet $R$, Boubred F, et al. Neurodevelopmental outcome at 3 years of age of infants born at less than 26 weeks. Arch Pediatr 2016; 23: 927-34. [CrossRef]

20. Grunau RE, Whitfield MF, Fay TB. Psychosocial and academic characteristics of extremely low birth weight $(<800 \mathrm{~g})$ adolescents who are free of major impairment compared with term-born control subjects. Pediatrics 2004; 114: 725-32. [CrossRef]

21. Hamilton BE, Minino AM, Martin JA, Kochanek KD, Strobino DM, Guyer B. Annual summary of vital statistics: 2005 Pediatrics 2007; 119: 345-60.

22. Marlow N, Wolke D, Bracewell MA, Samara M, for the EPICure Study Group. Neurologic and developmental disability at six years of age after extremely preterm birth. New Eng J Med 2005; 352: 9-19. [CrossRef]

23. Johnson EO, Breslau N. Increased risk of learning disabilities in low birth weight boys at age 11 years. 2000; 47: 490-500.

24. Vohr BR, Wright LL, Dusick AM, Mele I, Verter J, Steichen JJ, et al. Neurodevelopmental and functional outcomes of extremely low birth weight infants in the national institute of child health and human development neonatal research network, 1993-1994. Pediatrics 2000; 105: 1216-26. [CrossRef]

25. Bhutta AT, Cleves MA, Casey PH, Cradock MM, Anand KJS. Cognitive and behavioral outcomes of school-aged children who were born preterm: a metaanalysis. Jama 2002; 288: 728-37. [CrossRef]

26. Cheong, JLY, Burnett AC, Treyvaud K, Spittle AJ. Early environment and long-term outcomes of preterm infants. J Neural Transm 2020; 127: 1-8. [CrossRef]

27. Hollebrandse NL, Spittle AJ, Burnett AC, Anderson PJ, Roberts G, Doyle LW, et al. School-age outcomes following intraventricular haemorrhage in infants born extremely preterm. Arch Dis Child Fetal Neonatal Ed 2021; 106: 4-8. [CrossRef]

28. Hack M, Schluchter M, Cartar L, Rahman M, Cuttler L, Borawski E. Growth of very low birth weight infants to age 20 years. Pediatrics 2003; 37: 668-73. [CrossRef]

29. Davidovitch M, Kuint J, Lerner-Geva L, Zaslavsky-Paltiel I,Rotem RS, Chodick G, et al. Postnatal steroid therapy is associated with autism spectrum disorder in children and adolescents of very low birth weight infants. Pediatr Res 2020; 87: 1045-51. [CrossRef] 